though there is widespread agreement that the prevailing rules should go, there is meager accord on those which should take their place. Much that is proposed would simply retain the concepts but rearrange the categories..$^{52}$ It might be rewarding to explore the possibilities of abolishing the "general"-"special" damage categories completely, rather than seek to realign them. If by so doing, attention can be directed to all the facts comprising the injury rather than to the words alleged to have produced it, then would the law have moved toward realistic treatment of words intended to damage.

\title{
DISCOVERY OF GOVERNMENT DOCUMENTS UNDER THE FEDERAL RULES
}

The advent of the liberal discovery provisions of the Federal Rules of Civil Procedure ${ }^{x}$ has brought in its wake a renewed discussion of an old problem: when should documents in the possession of the executive departments of the government be considered privileged from disclosure? ${ }^{2}$ The resolution of this question involves not only the balancing of the respective rights and needs of private litigants and the government in its various litigious capacities, ${ }^{3}$ but also a delineation of the powers of the executive and the courts in an area where their duties overlap. 4

Law of Defamation, 33 Ill. L. Rev. 669 (r939); Carr, The English Law of Defamation, I8 L.Q. Rev. 255, 388 (1902); Donnelly, Law of Defamation-Proposals for Reform, 33 Minn. L. Rev. 609 (r949); Committee on the Law of Defamation: The Porter Report, r 2 Modern L. Rev. 2I 7 (r949); Faulks, op. cit. supra note 3 r.

${ }_{52}$ See for examples, Paton, op. cit. supra note $5 \mathrm{I}$; Donnelly, op. cit. supra note $5 \mathrm{I}$; Faulks, op. cit. supra note 3 I.

I Rule 34,28 U.S.C.A. foll. $\$ 2072$ (I950): "Upon motion of any party showing good cause therefor ... the court in which an action is pending may ( $I$ ) order any party to produce and permit the inspection and copying or photographing . . . of any designated documents, papers, books, accounts, letters, photographs, objects, or tangible things, not privileged, which constitute or contain evidence material to any of the matters within the scope of the examination permitted. ..." Rules 26-32, together with Rule 45 (b) and (d), authorize the issuance of similar orders to persons not parties to the action; these orders are also subject to the defense of privilege. Park Ridge Corp. v. Elias, 3 F.R.D. 93 (I943). As for the use of other defenses provided by the Rules, in the context of government litigation, see Pike and Fischer, Discovery against Federal Administrative Agencies, 56 Harv. L. Rev. II25 (1943); to this list should be added the "work-product" limitation laid down in Hickman v. Taylor, 329 U.S. 495 (I947).

For a general discussion of the discovery procedure, see Pike and Willis, Federal Discovery in Operation, 7 Univ. Chi. L. Rev. 297 (I940); Holtzoff, Instruments of Discovery under Federal Rules, 4 X Mich. L. Rev. 205 (I942).

2 United States v. Burr, 25 Fed. Cas. I, 37, I9I (C.C. Ky., I806).

3 Recent cases suggest that the treatment of the government's claim of privilege might depend on whether the government is acting in a sovereign or a proprietary capacity. See cases cited note 46 infra.

4 See text at notes $I_{3}-I_{5}$ infra. 
The government's claim that a document is protected from disclosure by a particular privilege should be distinguished from the ancient plea of sovereign immunity, which makes a blanket denial to the application of the discovery procedure against the government. 5 The latter argument, which assumes that the mechanisms provided in the Federal Rules for compelling disclosure of documents and information are technically bills of discovery and therefore may not be used against the sovereign without its consent, ${ }^{6}$ has not been accepted by the courts, ${ }^{7}$ nor seriously urged by the government.

There are a number of distinct and separable privileges which may be invoked to support the government's refusal to produce documents. The privilege accorded to military secrets ${ }^{8}$ needs no comment. The well-established privilege of the government not to reveal the identity of "informers"' finds justification in the government's receiving information which presumably it could not otherwise obtain. ${ }^{\text {xo }} \mathrm{A}$ similar principle underlies the privilege which protects reports received by the government from individuals under compulsion of statute. ${ }^{\mathrm{In}}$ The foregoing privileges have not caused much controversy, since they are comparatively specific. There are, however, instances not covered by these privileges where nondisclosure might be justified. In order to fill this gap there has grown

5 Even this theory did not preclude all discovery against government agencies, since the immunity was not always available to officers of the sovereign. Osborn v. Bank of the U.S., 9 Wheat. (U.S.) 738 (I824); United States v. Lee, I06 U.S. I96 (I882).

${ }^{6}$ O'Reilly, Discovery against the United States: A New Aspect of Sovereign Immunity? 21 N.C. L. Rev. I (1942).

7 United States v. General Motors Corp., 2 F.R.D. 528 (Ill., I942); cf. Fleming v. Bernardi, I F.R.D. 624 (Ohio, I94I). The courts' position seems to be justified by the expressed scope of the Rules: "These rules govern the procedure in the United States district courts in all suits of a civil nature ... with the exceptions stated in Rule 8I" (Rule I). Rule 8I specifies certain forms of actions which are not governed by the Rules, but makes no exceptions as to parties. The rule of construction which excludes the sovereign from the operation of any legislative act unless specifically mentioned (Dollar Savings Bank v. United States, I9 Wall. (U.S.) 227 (1873)) would seem inapplicable here, since the United States is mentioned wherever an exception is to be made in its favor: Rules I2(a), $\mathrm{r}_{3}(\mathrm{~d}), \mathrm{I}_{7}(\mathrm{a}), 25$ (d), 37 (f), 39(c), 54 (d), 55(e), 62(e), 2 Moore, Federal Practice $\S$ ro5 (2d ed., r948). Judge Clark has stated that "where we have felt it necessary we have provided special rules as to the Government. . . . [I]t was our theory that except as we made special provisions these rules apply to the United States as a litigant as much as to anyone else." American Bar Association: Proceedings of the Institute at Washington $5^{\circ}$ (I939). Although this statement might be construed as limiting the operation of the discovery procedures against the government to those cases where it is a party to the action, such a distinction seems to be irrelevant to the issue of privilege. See text at note $4 \mathrm{I}$ infra.

${ }^{8}$ U.S. v. Haugen, 58 F. Supp. 436 (Wash., I944); Pollen v. Ford Instrument Co., 26 F. Supp. 583 (N.Y., 1939).

9 In re Quarles \& Butler, 158 U.S. 532 (1894); Vogel v. Gruaz, Iro U.S. 3 II (1884).

10 Dean Wigmore contends that this particular privilege should cover only the identity of the informer and not the content of the communication. 8 Wigmore, Evidence $\$ 2374$, at 755 . But see note 44 infra.

${ }^{2 x}$ Regulations made pursuant to 26 U.S.C.A. $\$ 55$ (I948) prohibit disclosure of individual income tax returns. O'Connell v. Olsen \& Ugelstadt, Io F.R.D. I42 (Ohio, 1949). 
up a fourth category of privilege, which bars disclosure when it would be "prejudicial to the public interest."

The preliminary question raised by such a claim of privilege is whether the court or the executive agency asserting the privilege is to make the decision as to the status of the material in question. In United States v. Burr, ${ }^{13}$ the court had before it the question of whether a subpoena duces tecum could issue to the President, and whether the entire contents of certain letters in his possession must be produced on motion and affidavit of the defendant as to their materiality. Chief Justice Marshall stated that the subpoena would issue; and although he ruled that there was insufficient evidence to decide whether the parts of the letter in question could be withheld, the discussion makes it clear that he considered the ultimate decision to be in the hands of the court. ${ }^{I_{4}}$ It is not surprising that the executive agencies have taken the opposite position, contending that all discretion as to the need for secrecy rests with the agency asserting the privilege. ${ }^{15}$ The acquiescence of many courts in this latter view can be seen in cases involving agency regulations which prohibit any member of the department from disclosing official papers without express authority from the head of the department, under penalty of fine and discharge from office. ${ }^{16}$

${ }_{12}$ Shallow v. Markert Mfg. Co., I75 Misc. 6r3, 24 N.Y.S. 2d 823 (I94I); cf. Jacoby v. Delfiner, 183 Misc. 280 , 5 I N.Y.S. (2d) 478 (I944).

1325 Fed. Cas. I (C.C. Ky., r806).

${ }^{14}$ "'The president, although subject to the general rules which apply to others, may have sufficient motives for declining to produce a particular paper, and those motives may be such as to restrain the court from enforcing its production... A the same time, the court could not refuse to pay proper attention to the affidavit of the accused." Ibid., at I9x-92.

15 "The courts have repeatedly held that they will not and cannot require the executive to produce such papers when in the opinion of the executive their production is contrary to the public interest. The courts have also held that the question whether the production of the papers would be against the public interest is one for the executive and not for the courts to determine." 40 Ops. Atty. Gen. 45, 49 (194r). Of the cases cited by the Attorney General as authority for this statement, only one, Appeal of Hartranft, 85 Pa. 433 (I877), involved this issue. Hartranft, the Governor of Pennsylvania, was appealing from an order allowing attachment to issue against him because of his failure to respond to a subpoena directing him to appear before a grand jury. The court dismissed the order, saying that his appearance would have been futile since, as governor, he could not be compelled to reveal any information he had received in the course of his official duties. This proposition was claimed to be a necessary inference from the tri-partite nature of the government: if the executive is to be responsible for the carrying out of the laws, he must be deemed to have final discretion, as against other branches of the government, over matters in his department. The dissenting opinion pointed out that the question of the applicability of the privilege of nondisclosure could have been construed equally well as one falling within the duties of the judiciary.

${ }^{16}$ These regulations are made pursuant to R.S. $\S \mathrm{x} 6 \mathrm{r}$ ( 1878 ), 5 U.S.C.A. $\S 22$ (I927), which provides that "the head of each department is authorized to prescribe regulations, not inconsistent with law, for the government of his department, the conduct of its officers and clerks, the distribution and performance of its business, and the custody, use, and preservation of the records, papers, and property appertaining to it." The constitutionality of this statute, which has been in force since 1789 (r Stat. at Large 28) was affirmed in Ex parte Curtis, I06 U.S. 37I (I882). The statute is not a delegation of legislative power, although regulations made pursuant thereto have the force of law. Butler v. White, 83 Fed. 578,589 (C.C. Va., I897). 
Privilege against disclosure on the strength of such regulation was first asserted in a line of cases which arose out of a conflict between the Commissioner of Internal Revenue and some of the state governments. A number of internal revenue collectors were committed to jail for contempt when they refused to disclose documents or information relating to the sale of federal tax stamps to liquor dealers, during the prosecutions of alleged offenders of the state prohibition laws. In all but one case, ${ }^{17}$ the collectors were released on writs of habeas corpus, ${ }^{18}$ but the courts, anxious not to invite a storm of protest over invasion of states' rights by the federal judiciary, ${ }^{29}$ used some very broad language about the force and limitations of the departmental regulations. In the earliest case in this group, ${ }^{20}$ the court stated that "Congress has given to the commissioner of internal revenue, without qualification the power to make and enforce upon his subordinate officers all reasonable regulations in the matter of the collection of internal revenue. These regulations are not to be questioned by this court, but must be upheld and enforced. ..."

In Boske v. Comingore, ${ }^{22}$ it was argued that a regulation resulting in a blanket prohibition against disclosure was "inconsistent with law." The Supreme Court disposed of this contention with the statement that "[ $t]$ here is certainly no statute which expressly or by necessary implication forbade the adoption of such a regulation. That being the case, we do not perceive upon what ground the regulation in question can be regarded as inconsistent with law." the statute under which the regulation was promulgated was not intended to create new rules of evidence, ${ }^{25}$ the court's reasoning appears to have been based

17 In re Hirsch, 74 Fed. 928 (C.C. Conn., 1896), upholding the action of the state court.

${ }^{8}$ In re Weeks, 82 Fed. 729 (D.C. Utah, 1897); Boske v. Comingore, 177 U.S. 459 (1900); In re Lamberton, I24 Fed. 446 (D.C. Ark., I903); Stegall v. Thurman, I 75 Fed. $8 \mathrm{I}_{3}$ (D.C. Ga., r9I0); Harwood v. McMurtry, 22 F. Supp. 572 (Ky., r938).

xg "It is not that the United States has any desire to interfere with or prevent the enforcement of any criminal law which the people of the state may see fit to enact. It is simply a question whether, when the officers of the state, in attempting to enforce one of her laws seek to transgress ... what is tantamount to a statute of the United States [see note $2 \mathrm{I}$ infra] it is not the duty of the federal courts ... to see to it that the national law is upheld." In re Huttman, 70 Fed. 699 at 703 (Kan., I895).

20 Ibid.

${ }^{2 x}$ Ibid., at $70 x$. At this time the only "regulations" in force were two letters addressed to individual collectors by the Commissioner. In re Hirsch, 74 Fed. 928, $93 x$ (C.C. Conn., I896).

${ }^{22}$ I 77 U.S. 459 (I900). By this time, a specific prohibition against disclosure had been promulgated and it was conceded that "[i]f these regulations were such as the Secretary could legally prescribe ... the state authorities were without jurisdiction to compel the Collector to violate them." Ibid., at $46 \%$.

${ }^{23}$ See note 16 supra.

${ }^{44}$ Boske v. Comingore, I77 U.S. 459,469 (I900). And a court cannot so find "unless [the regulation] ... is plainly and palpably inconsistent with law." Ibid., at 470 .

${ }^{25}$ In reviewing the legislative history of the statute, the court in Butler v. White, 83 Fed. 578,581 (C.C. Va., I897), said that " it is in no sense a delegated power of legislation. The evident purpose of congress was to furnish each department with authority to regulate the conduct of its officers and employees." 
on the assumption that pre-existing rules of evidence gave the commissioner complete discretion in this matter, even as against a court. ${ }^{26}$ No authority was cited for such an assumption ${ }^{27}$ and in view of the precedent of United States $v$. Burr, the assumption seems questionable.

The issue of whether the court or the executive is to decide questions of privilege has occasionally been obscured by stating the alternative to executive discretion in terms of public access to all government records. ${ }^{28}$ Thus it has been argued that to allow judicial examination of the material claimed to be privileged would be tantamount to denying all privilege, since such examination would necessarily involve full disclosure to the world. This dire prediction need not, and has not, come true, as evidenced by the cases where the court has been willing to examine the material and safeguard privileged information by requiring only partial disclosure, ${ }^{29}$ or disclosure only to the persons immediately concerned, ${ }^{30}$ or by postponing disclosure until an appropriate time, ${ }^{31}$ or by not allowing disclosure at all..$^{32}$

A more serious criticism of judicial handling of the privilege question is the fact that the head of an executive agency may have the advantage of a more complete picture than a court can have of the consequences of disclosure in a particular case. However, the most sensitive matters of national defense and law enforcement are to a great degree protected by the specific privileges men-

${ }^{26}$ The decision could have been based on the narrower ground of the privilege of nondisclosure of information given under compulsion of statute. The court mentioned this privilege, but suggested the existence of broader "reasons of public policy" and added, "[a]t any rate, the Secretary deemed the regulation in question a wise and proper one." Boske v. Comingore, I77 U.S. 459,470 (1900).

${ }^{27}$ With the exception of Appeal of Hartranft, 85 Pa. 433 (1877), none has been found.

${ }^{28}$ In re Comingore, 96 Fed. 552, 558 (D.C. Ky., I899); cf. Appeal of Hartranft, $85 \mathrm{~Pa}$. 433, 444 (I877).

29 Walling v. Richmond Screw Anchor Co., 4 F.R.D. 265 (N.Y., r943); cf. Bowles v. Ackerman, 4 F.R.D. 260 (N.Y., I945). This has also been done in cases not involving the government, Gordon, Wolf, Cowen Co. v. Independent Halvah Candies, 9 F.R.D. 700 (N.Y., I949).

30 United States v. Burr, 25 Fed. Cas. I, I92 (C.C. Ky., I806); in Evans v. United States, I8 U.S. L. Week 2573 (D.C. La., June 20 , I950), the court said: 'It is not the exclusive right of any such agency of the Government to decide for itself the privileged nature of such documents, but the court is the one to judge of this when such contention is made. This can be done by presenting to the judge, without disclosure in the first instance to the other side, whatever is claimed to have that status. The court then decides whether it is privileged or not." Cf. United States v. Cotton Valley Operators Committee, 9 F.R.D. 7 I9 (La., I949), aff'd (by equally divided court) I8 U.S.L. Week 3297 (Apr. 25, I950).

${ }^{3 x}$ U.S. v. Schine Chain Theatres, Inc., 4 F.R.D. 109 (N.Y., I944). The technique of postponing discovery has been utilized to protect trade secrets in advance of trial, Western States Machine Co. v.S. S. Hepworth Co., I F.R.D. 766 (N.Y., I94I); whether or not this approach is feasible may be the determinative factor in ruling on a motion for discovery against the government in law enforcement cases; see note 44 infra.

${ }^{32}$ United States v. Kohler Co., 9 F.R.D. 289 (Pa., I949); United States v. Deere \& Co., 9 F.R.D. 523 (Minn., 1949). 
tioned above, which have generally been respected by the courts. ${ }^{33}$ It should not be presumed that judicial discretion over other claims of privilege would produce results "prejudicial to the public interest." On the contrary, where the courts have assumed the responsibility of examining the claim of privilege, they have gone out of their way to make sure that "secret" information was not involved before requiring disclosure of the government. ${ }^{34}$ These courts have recognized that discovery, even under the Federal Rules, is not a matter of unqualified right, ${ }^{35}$ and the requests have been denied where the moving party failed to demonstrate good cause, ${ }^{36}$ and where the court felt that the disadvantages of "harassment ... and ... disruption of the organization" would outweigh the benefits to be derived from disclosure. ${ }^{37}$ Although judicial examination of the grounds which are claimed to give rise to the privilege does not guarantee that the proper balance will always be struck between the interests of the individual litigant and the "public interest," it can serve to counteract a natural propensity on the part of the agencies involved to overestimate the importance of their office procedures and activities when they are judging their own cause. ${ }^{38}$

${ }^{33}$ See notes 9-II supra. In a separate concurring opinion in Bank Line, Ltd. v. United States, I63 F. 2d I33, I39 (C.A. 2d, I947), Judge Clark suggested that even where the facts would bring the matter within one of the specific privileges, the court should make a separate ruling in every case: "During war, courts must respect decisions of the armed forces as to the need for concealment, but $I$ think no general principle of refusing discovery on a general statement of prejudice to its best interest should be applied to any branch of the government, including the armed forces."

34 In Cresmer v. United States, 9 F.R.D. 203 (D.C. N.Y., I949), an action brought under the Federal Tort Claim Act, 62 Stat. 982 (r948), 28 U.S.C.A. 267 I (1950), the government's assertion of privilege against disclosure was denied by a ruling to the effect that the Act placed the United States "on a par with ordinary litigants." (It should be noted that in this case the government was acting in a proprietary capacity; see note 43 infra.) Nevertheless the court, on its own motion, examined the report in question first, in order "to make sure that ... [it] contained no military or service secrets which would be detrimental to the interests of the armed forces of the United States or to the National Security." 9 F.R.D. 204.

35 U.S. v. 5 Cases, etc., 9 F.R.D. 8 (Conn., 1949); U.S. v. Kohler Co., 9 F.R.D. 289 (Pa., 1949).

${ }^{36}$ "I cannot see the necessity of a court order to enable a claimant to pierce 'the dark veil of secrecy over pertinent facts' when without an order he can poke his head within the veil and make his own observation." U.S. v. 5 Cases, etc., 9 F.R.D. 8I, 83 (Conn., I949). Cf. Portland v. Dravo Corp., 4 F.R.D. 305 (Pa., 1945).

37 Consolidated Water Power \& Paper Co. v. Bowles, I5o F. 2d 960 (Emerg. App., 1945).

${ }^{38}$ Dean Wigmore's description of what he terms typical office procedure where a regulation prohibiting disclosure is in effect (see note I6 supra) points out the potential danger: "This general order becomes a routine dogma in the minds of all subordinates. An application now arrives for a copy of a record material in litigation. . . . The subordinate at that lowest point, obsessed by the general dogma against disclosure, prepares a reply denying the application; he will usually not have the initiative or courage to propose an exceptional use of discretion in favor of the application. This draft reply is sent up, 'through channels,' each one treating it in routine fashion, until it reaches the departmental head or other chief officer whose signature is necessary. Arriving in a ponderous pile of daily draft correspondence, it receives that necessary signature without further consideration... . Thus, the chief officer himself [who 
The greatest single advantage of allowing judicial inquiry into the government's claims of privilege is the flexibility which appears to be lacking under the doctrine of executive discretion. There have been a number of instances under the Rules where disclosure has been required of the government in spite of an assertion of privilege. ${ }^{39}$ In many of these cases, however, the disclosure was ordered on the theory that although the particular agency has sole discretion as to whether disclosure should be permitted when requested in a suit between private parties, the privilege of nondisclosure is automatically waived when the agency has instituted the action..$^{\circ}$ The government is thus faced with the alternatives of revealing information, the disclosure of which it deems unwise, or abandoning its case, ${ }^{4 \mathrm{I}}$ without any judicial determination of the merits of its claim. This test ignores the question, fundamental to any decision regarding a claim of privilege, of the existence of circumstances extraneous to the litigation which make it desirable that the material remain confidential..$^{2}$ In applying a rule as mechanical as this waiver test, a court is not able to consider the very important factor of the nature of the capacity in which the government appears in court.

Although justice may require that the government be treated like an ordinary litigant when it is acting in a proprietary capacity, ${ }^{43}$ additional elements

is usually the only one with power to authorize disclosure] is rarely given an opportunity to pass intelligently on the precise need for that document in the litigation, or upon the actual extent to which any important State interest might demand its withholding." 8 Wigmore, Evidence, $\$ 2378 \mathrm{a}$, at 793 . Even if we assume that this condemnation cannot be justifiably directed at all federal agencies, the existence of this procedure in some cases is not beyond the realm of possibility.

39 United States v. 300 Cans, etc., 7 F.R.D. 36 (Ohio, I947); Bowles v. Ackerman, 4 F.R.D. 260 (N.Y., I945). In Bowles v. Dashiel, 72 F. Supp. 2 r9 (Ore., r946), an action by the OPA administrator for damages for over-ceiling prices, the court requested the defendant to file a motion under Rule 34, requesting documents revealing the basis of the administrator's determinations; presumably the motion was filed and granted. Cf. Bowles v. Karp, 3 F.R.D. 327 (Ky., 1944).

${ }^{40}$ Fleming v. Bernardi, I F.R.D. 624 (Ohio, I94I); United States v. General Motors Corp., 2 F.R.D. 528 (Iil., 1942). This is sometimes referred to as the "public-private" test; the terminology can probably be traced to the assertion that "in a suit between private parties" government papers have a privileged status. ${ }_{5}$ Ops. Atty. Gen. 378 (1877).

4 Rule 37 (b) (3), 2 U.S.C.A. foll. \& 2072 (1950).

42 In criminal prosecutions, the government's claim of privilege has often been denied, not on a theory of waiver, but because "[s]o far as they directly touch the criminal dealings, the prosecution necessarily ends any confidential character the documents may possess." United States v. Andolschek, I42 F. 2d 503, 506 (C.A. 2d, I944); accord, United States v. Krulewitch, 145 F. 2d 76 (C.A. 2d, 1944); United States ex rel. Touhy v. Ragen (C.A. 7th, 1950), $180 \mathrm{~F}$. $2 \mathrm{~d} 32 \mathrm{I}$. On this basis, it is apparent that these cases cannot be cited as authority for the waiver theory; but see Bowles v. Ackerman, 4 F.R.D. 260 (NY., I945).

${ }_{43}$ This proposition was adopted in the Federal Tort Claims Act, 62 Stat. 982 (I948), 28 U.S.C.A. 267 I (I950). Apart from such specific statutory language, once a court has accepted the doctrine of executive discretion, the waiver theory is the only means by which the court can "logically" refuse to recognize the government's claim of privilege. This has led to some rather tenuous reasoning in an effort to make a "public" case out of a "private" one in order to deny the government's privilege. See Zimmerman v. Poindexter, 74 F. Supp. 933 (Hawaii, 
are involved when the government comes into court in its role as a sovereign or law-enforcing agency. In the latter situation there exist somewhat the same considerations which underlie the "informers' privilege"; the government should not be forced to reveal information when the very fact of disclosure might impede future law-enforcement activities. 44 To avoid this by forcing the government to give up its case is to protect the means at the expense of the goal. Moreover, it is conceivable that in certain situations, disclosure of the requested material might entail a premature publication of related investigations or the revealing of fact-finding techniques which are effective only because they are kept secret. ${ }^{45}$ These considerations cannot be given their full effect under pat notions of waiver; but where the courts follow the practice of judicial examination of the asserted privilege, the implications of the distinction between the government as a proprietor and as the enforcer of law can be, and have been, recognized. $4^{6}$

It is not unlikely that the doctrine of executive discretion has gained as much force as it has because of an unwillingness on the part of the courts to face the enforcement problem which could arise under the opposite view.47 Although there is some dictum to the effect that a court might use the ordinary remedies to enforce its orders against the executive branch of the government, $4^{8}$ it is

1947), noted in 58 Yale L.J. 993 (1949). The interdependence of these theories may be inferred from the fact that in a few recent anti-trust prosecutions, where the courts refused to accept the doctrine of executive discretion and insisted on making their own determination of the applicability of a privilege, the waiver theory was not even mentioned. "[T]he inevitable consequence of the Government's submitting itself ... to litigation with private persons" was not the automatic waiver of all privilege, but the duty to submit the question to the court, who "then decides whether it is privileged or not." Evans v. United States, I8 U. S. L. Week 2573 (D.C. La., June 20, 1950). That this procedure need not entail denial of all privilege, see notes 29-32 supra.

44 The anti-trust prosecutions are an example. The material which is often requested of the government is that which the government has received from companies that have dealt with the defendant, regarding the business practices of the latter. United States v. Kohler Co., 9 F.R.D. 289 (Pa., 1949); United States v. Deere \& Co., 9 F.R.D. 523 (Minn., 1949). It is probable that much of this information is obtained on the strength of the government's practice of keeping such sources confidential; disclosing the documents would probably involve disclosure of the source. The fact that some of the information contained in the documents may later be revealed at the trial, or upon pre-trial proceedings, does not warrant complete disclosure before that time.

45 The denial of discovery in such a case might also be supported by analogy to the reasoning underlying the "work-product" test laid down in Hickman v. Taylor, 329 U.S. 495 (1947).

${ }_{46}^{6}$ United States v. Deere \& Co., g F.R.D. ${ }_{223}$ (Minn., I949); United States v. Kohler Co., 9 F.R.D. 289 (Pa., 1949).

${ }^{47}$ See Jacoby v. Delfiner, I83 Misc. 280, 5 I N.Y.S. (2d) 478 (1944): "an order of the court directing the United States Department of Justice to furnish plaintiffs with the information desired need not be honored by that federal agency and, accordingly, the order sought herein would be a mere futility."

$1^{8}$ In Thompson v. German Valley R. Co., 22 N.J. Eq. III (I87r), the court stated, at II5, that "[i]t is possible that there may be cases where courts, from the conduct of an Executive, might deem it proper to proceed against him for contempt." 
"not clear" whether such action would be successful.49 Even if it could be done, the propriety of such action is debatable. Nevertheless, the weight to be given to this consideration should not be exaggerated. The problem would arise only where the government was not a party to the action-in a "private" suitsince otherwise a court can avoid an impasse by resorting to the provisions in the Rules for entering a default judgment against a disobedient party. ${ }^{5 \circ}$ Even in the former situation it would seem that the natural reluctance of the judiciary and the executive to proceed to the point of open conflict would tend to make the courts amenable to assertions of privilege when strongly contended for by the executive, while minimizing the likelihood of the executive's absolute refusal to produce information which a court has ordered to be disclosed. The possibility that a court, in a rare case, might have to meet the enforcement problem unsuccessfully does not seem to be sufficient justification for a court, in every case, to "abdicat[e] an inherent judicial function of determining the facts upon which the admissibility of evidence in a case depends." ${ }_{5 I}$

\section{PROOF REQUIREMENTS IN ANTI-TRUST SUITS: THE OBSTACLES TO TREBLE DAMAGE RECOVERY}

Some prerequisites for private recovery under the treble-damage provisions of the anti-trust laws may be considered relatively well settled. Injury must be to a "business or property" interest" and must be "proximately caused" 3 by a violation" of those laws. A creditor, for example, does not suffer a "direct in-

492 Moore, Federal Practice $\$ 34.05$, n. I (xst ed., I938).

${ }^{50}$ United States v. Cotton Valley Operators Committee, 9 F.R.D. 721 (La., I949), aff'd (by equally divided court) I8 U. S. L. Week 3297 (Apr. 25, I950). It has been suggested that the public-private test (see text at note 40 supra) may be justified because of this consideration, Government Privilege against Disclosure of Official Documents, 58 Yale L.J. 993, 998 (1949).

sז Zimmerman v. Poindexter, 74 F. Supp. 933 (Hawaii, I947).

${ }^{x}$ Section 7 of the Sherman Anti-Trust Act, 26 Stat. 209 (I8go), I5 U.S.C.A. $\$$ I5 (I94r), is as follows: "Any person who shall be injured in his business or property by any other person or corporation by reason of anything forbidden or declared to be unlawful by this act, may sue therefor in any circuit court of the United States in the district in which the defendant resides or is found, without respect to the amount in controversy, and shall recover threefold the damages by him sustained, and the cost of suit, including a reasonable attorney's fee."

Section 4 of the Clayton Act, 38 Stat. 730 (I9I4), I5 U.S.C.A. \& 15 (r94I), adds only that 'the defendant may be sued in the district in which "he has an agent."

2 Glenn Coal Co. v. Dickinson Coal Co., 72 F. 2d 885 (C.A. 4th, r934); Louisiana Farmers P. U. v. Great A. \& P. Tea Co., 4 O F. Supp. 897 (Ark., I94I); American Banana Co. v. United Fruit Co., 2I3 U.S. 347 (I $(909)$. "While the antitrust laws are for the public benefit . . an ... action to recover damages is personal ... and not for the benefit of the public. [Plaintiff] must seek personal pecuniary damages." Maltz v. Sax, I34 F. 2d 2, 5 (C.A. 7th, I943). I Toumlin's Anti-Trust Laws $\$ 20.8$ (1949).

3 Package Closure Corp. v. Sealright Co., I4r F. 2d 972 (C.A. 2d, I944).

1 Various activities prohibited by the anti-trust laws have led to recovery of treble damages: monopolization and conspiracies to monopolize, Eastman Kodak Co. v. Southern Photo Ma- 